\title{
Agrobacterium tumefaciens T-DNA Integration and Gene Targeting in Arabidopsis thaliana Non-Homologous End-Joining Mutants
}

\author{
Qi Jia, ${ }^{1}$ Paul Bundock, ${ }^{1,2}$ Paul J. J. Hooykaas, ${ }^{1}$ and Sylvia de Pater ${ }^{1}$ \\ ${ }^{1}$ Department of Molecular and Developmental Genetics, Institute of Biology, Leiden University, Sylviusweg 72, \\ 2333 BE Leiden, The Netherlands \\ ${ }^{2}$ Keygene N.V., P.O. Box 216, 6700 AE Wageningen, The Netherlands
}

Correspondence should be addressed to Sylvia de Pater, b.s.de.pater@biology.leidenuniv.nl

Received 31 August 2011; Accepted 30 October 2011

Academic Editor: Frederick Meins

Copyright (C) 2012 Qi Jia et al. This is an open access article distributed under the Creative Commons Attribution License, which permits unrestricted use, distribution, and reproduction in any medium, provided the original work is properly cited.

\begin{abstract}
In order to study the role of AtKu70 and AtKu80 in Agrobacterium-mediated transformation and gene targeting, plant lines with a T-DNA insertion in AtKu80 or AtKu70 genes were functionally characterized. Such plant lines lacked both subunits, indicating that heterodimer formation between AtKu70 and AtKu80 is needed for the stability of the proteins. Homozygous mutants were phenotypically indistinguishable from wild-type plants and were fertile. However, they were hypersensitive to the genotoxic agent bleomycin, resulting in more DSBs as quantified in comet assays. They had lower end-joining efficiency, suggesting that NHEJ is a critical pathway for DSB repair in plants. Both Atku mutants and a previously isolated Atmre11 mutant were impaired in Agrobacterium T-DNA integration via floral dip transformation, indicating that AtKu70, AtKu80, and AtMre11 play an important role in T-DNA integration in Arabidopsis. The frequency of gene targeting was not significantly increased in the Atku80 and Atku70 mutants, but it was increased at least 10-fold in the Atmre11 mutant compared with the wild type.
\end{abstract}

\section{Introduction}

Genetic modification of plants is now routinely performed. Transformation can be done by various methods and vectors including Agrobacterium tumefaciens. It has been observed that transgenes integrate at fairly random positions via non-homologous recombination (NHR) in variable copy numbers in the plant genome. This may cause position effects (like silencing of transgenes) and mutation of genes at the integration site. Therefore, it would be an advantage if integration could be targeted to a specific locus. Targeted DNA integration by homologous recombination (HR), also called gene targeting (GT), is efficient in yeast but a very rare event in somatic cells of higher eukaryotes, like animals and plants. DNA repair mutants of the model yeast Saccheromyces cerevisiae were used to identify the genes involved in the integration of the T-DNA. Results showed that genes, which are involved in non-homologous end-joining (NHEJ), are required for integration of the Agrobacterium tumefaciens
T-DNA by non-homologous recombination [1]. NHEJ is one of the major DNA repair pathways used to repair doublestrand breaks (DSBs). It does not require any homologous sequences and can function throughout the cell cycle [2]. The ends are directly ligated, but this is often accompanied by small deletions and insertions. The other DSB repair pathway is homologous recombination (HR) involving extensive DNA sequence homology between the interacting molecules. HR occurs during the late $S$ to G2 phases of the cell cycle when the sister chromatid is in close proximity as repair template. Genes involved in homologous recombination, like Rad51 and Rad52, are required for the targeted integration of T-DNA in yeast [3]. Transient or stable inactivation of the NHEJ pathways was shown to be a very efficient method to improve targeted integration in yeast and fungi [4-9]. Estimates of GT frequencies in several different plant species vary from $10^{-4}$ to $10^{-6}$ [10-17]. For more than two decades, researchers have looked for ways to improve GT in plants. Since GT was significantly increased in NHEJ mutants in 
yeast and fungi, a similar approach to improve GT frequency in Arabidopsis thaliana may be successful.

The pathway of NHEJ in S. cerevisiae and mammals has been extensively characterized. In mammals, conserved proteins that are involved in NHEJ include the following: DNAdependent protein kinase (DNA-PK), Ku70, Ku80, DNA ligase IV (Lig4), Xrcc4, and Cernunnos/XLF [18, 19]. Orthologs of these proteins have been identified also in yeast, fungi and plants with the exception of DNA-PKcs, which does not seem to play a role in NHEJ in these organisms. $\mathrm{Ku}$ is an abundant nonhistone nuclear protein in human cells. However $\mathrm{Ku}$ is also found in the membrane and cytoplasm [20, 21]. Ku can shuttle from the cytoplasm to the nucleus dependent on the cell cycle status and external stimuli, like irradiation, alkylating agents, and hormones such as somatostatin $[22,23]$. Ku has an extremely high affinity to DNA ends and thus rapidly binds to DSBs in living cells [2].

In response to DNA damage, the Mre11-Rad50-Xrs2 (MRX) complex in yeast and its counterpart in mammals, called Mre11-Rad50-Nbs1 (MRN), function early as a key player in the DNA damage sensing, signaling, and repair mechanism of both HR and NHEJ pathways [24]. NHEJ is initiated by the recognition and binding of the $\mathrm{Ku}$ heterodimer consisting of Ku70 and Ku80 to the exposed DNA ends. In mammals the Ku heterodimer recruits DNA-PKcs and activates its kinase activity [25-27]. Once $\mathrm{Ku}$ is bound to the DNA ends, it can improve the binding equilibrium of the nuclease (Artemis: DNA-PKcs), the polymerases ( $\mu$ and $\lambda)$ and the ligase complex (XLF:XRCC4:Lig4) $[28,29]$. In this way, $\mathrm{Ku}$ serves as a scaffold of the subsequent protein assembly and stabilizes their enzymatic activities at a DNA end [19]. The following step is that the Lig4/XRCC4/XLF complex catalyzes the ligation and seals the joint [30], thereby restoring the genomic integrity. Lig4 has an exclusive function in NHEJ by forming a complex with XRCC4 through the BRCT domain in the C-terminus of Lig4 [31]. This complex associates with Pol $\chi$ family polymerases, Pol $\mu$, Pol $\lambda$, and terminal transferase, which fill in the short gaps generated during DNA end alignment and processing $[32,33]$. The Lig4/XRCC4 complex also has an impact on the association of Cernunnos/XLF which promotes the ligation of mismatched and noncohesive DNA ends [30, 34]. The NHEJ pathway is $\mathrm{Ku}$ dependent and is also called classical NHEJ (C-NHEJ). Another NHEJ pathway has been identified in C-NHEJ deficient cells, which is $\mathrm{Ku}$ independent, called back-up NHEJ (B-NHEJ) [35].

Previously, it was shown that several Arabidopsis NHEJ mutants (ecotype Wassilewskija, ws) were hypersensitive to DNA damage [36-41]. Results of Agrobacterium-mediated transformation were rather inconclusive, since in some reports the mutants were impaired in T-DNA integration $[37,42]$ whereas in other reports no effects could be observed $[38,40]$. Here we characterized two Arabidopsis lines (ecotype Columbia-0; Col-0), containing a T-DNA insertion in the AtKu70 and AtKu80 genes, respectively. Plants homozygous for the T-DNA insertions were analyzed for sensitivity to DNA damaging agents and it was shown directly that these proteins function in end-joining in plants. Agrobacteriummediated transformation and the frequency of gene targeting were analyzed in these Atku70 and Atku80 Col-0 mutants and in the Atku70 and Atmre11 mutants (ecotype ws) that were previously isolated by us $[36,43]$.

\section{Materials and Methods}

2.1. Plant Material. The Atku70 (SALK_123114) and Atku80 (SALK_016627) T-DNA insertion lines, ecotype Col-0, were obtained from the SALK T-DNA collection [44].

Arabidopsis was either grown on soil in a greenhouse at $21^{\circ} \mathrm{C}(16 \mathrm{~h}$ photoperiod) or in Petri dishes in a culture chamber $\left(21^{\circ} \mathrm{C}, 50 \%\right.$ relative humidity, $16 \mathrm{~h}$ photoperiod $)$.

2.2. Molecular Analysis of the Plant Lines. The T-DNA insertion sites were mapped with a T-DNA left-border- (LB-) specific primer LBal and a gene-specific primer. Pairs of gene-specific primers around the insertion site were used to determine whether the plants were homozygous or heterozygous for the T-DNA insertion, and the PCR products were sequenced. T-DNA right-border- (RB-) specific primers (SP205, SP206) were used to detect the T-DNA Right Border/vector junction. The sequences of all the primers are listed in Table 1. For southern blot analysis, DNA was extracted using the CTAB DNA isolation protocol [45] and digested with HindIII. DNA $(5 \mu \mathrm{g})$ was run on a $0.7 \%$ agarose gel and transferred onto positively charged Hybond$\mathrm{N}$ membrane (Amersham Biosciences) [45]. The hybridization and detection procedures were done according to the DIG protocol from the Roche Applied Sciences. The DIG probe was produced using the PCR DIG Labeling Mix (Roche) with specific primers SP271 and SP272 that amplified an $850 \mathrm{bp}$ fragment from the T-DNA of pROK2.

\subsection{Quantitative Reverse-Transcription PCR (Q-RT-PCR).} Leaves of 2-week-old plants were ground under liquid $\mathrm{N}_{2}$ in a Tissue Lyser (Retch). Total RNA was extracted from the leaf powder using the RNeasy kit (Qiagen) according to the supplied protocol. Residual DNA was removed from the RNA samples with DNaseI (Ambion) in the presence of RNase inhibitor (Promega). RNA was quantified, and $1 \mu \mathrm{g}$ of RNA was used to make cDNA templates using an iScript cDNA synthesis kit according to the manufacturer's instructions (Bio-Rad). Quantitative real-time PCR (Q-PCR) analyses were done using the iQ SYBR Green Supermix (BioRad). Specific fragments (about $200 \mathrm{bp}$ ) were amplified by pairs of primers around the T-DNA insertion sites using a DNA Engine Thermal Cycler (MJ Research) equipped with a Chromo4 real-time PCR detection system (Bio-Rad). The sequences of the primers are listed in Table 1 . The cycling parameters were $95^{\circ} \mathrm{C}$ for $3 \mathrm{~min} 40$ cycles of $\left(95^{\circ} \mathrm{C}\right.$ for $1 \mathrm{~min}$, $60^{\circ} \mathrm{C}$ for $40 \mathrm{~s}$ ) and $72^{\circ} \mathrm{C}$ for $10 \mathrm{~min}$. All sample values were normalized to the values of the house keeping gene Roc1 (primers Roc5.2, Roc3.3) and were presented as relative expression ratios. The value of the wild type was set on 1 .

2.4. Western Blotting. Leaves from plants grown on soil for 3 weeks were ground under liquid $\mathrm{N}_{2}$ in a Tissue Lyser (Retch). One hundred $\mu \mathrm{L}$ protein extraction buffer $(50 \mathrm{mM}$ Tris- $\mathrm{HCl}$ pH 7.5; 2 mM EDTA; 0.2 mM PMSF; 1 mM DTT; 
TABLE 1: Sequences of primers used for characterization of the T-DNA insertion lines and Q-PCR.

\begin{tabular}{|c|c|c|}
\hline Name & Locus & Sequence \\
\hline LBal & T-DNA LB & 5'-TGGTTCACGTAGTGGGCCATCG-3' \\
\hline SP111 & Atku80 & 5'-GAATTCCCCATGGAACAACAACAAGCAGTAGCAG-3' \\
\hline SP112 & Atku80 & 5'-CTCGACTTAGCTCTCGAGCATTGAC-3' \\
\hline SP119 & Atku70 & $5^{\prime}$-TGGGTTGCACAAGCACTACTGC-3' \\
\hline SP120 & Atku70 & 5'-GAATAGCCGGACGGAGTAAAGC-3' \\
\hline SP205 & T-DNA RB & $5^{\prime}$-ATCAAGCGTATGCAGCCGCC-3' \\
\hline SP206 & T-DNA RB & $5^{\prime}$-TTTGGAACTGACAGAACCGC-3' \\
\hline SP207 & Atku80 & 5'-GCGTCTTGGAGCAGGTCTCTTC-3' \\
\hline SP208 & Atku80 & 5'-GATGAAATCCCCAGCGTTCTCG-3' \\
\hline Q1 & Atku70 & $5^{\prime}$-TCTACCACTCAGTCAACCTG-3' \\
\hline Q2 & Atku70 & $5^{\prime}$-CAATAGACAAGCCATCACAG-3' \\
\hline Roc5.2 & Roc & $5^{\prime}$-GAACGGAACAGGCGGTGAGTC-3' \\
\hline Roc3.3 & $R o c$ & 5'-CCACAGGCTTCGTCGGCTTTC-3' \\
\hline SP271 & T-DNA & 5'-CCCGTGTTCTCTCCAAATG-3' \\
\hline SP272 & T-DNA & 5'-CAGGTCCCCAGATTAGCC-3' \\
\hline Q8 & BamHI & 5'-GTGACATCTCCACTGACGTAAG-3' \\
\hline Q9 & BamHI & 5'-GATGAACTTCAGGGTCAGCTTG-3' \\
\hline Q10 & GFP & 5'-CAAGCTGACCCTGAAGTTCATC-3' \\
\hline Q11 & GFP & 5'-GTTGTGGCGGATCTTGAAG-3' \\
\hline SP154 & $5^{\prime} \mathrm{PPO}$ & 5'-GGTGGTACTTTTAAGGCAATTCAG-3' \\
\hline SP155 & $5^{\prime} \mathrm{PPO}$ & 5'-GACAGAATTCCGGTGTTTGTAGAC-3' \\
\hline SP156 & $3^{\prime} \mathrm{PPO}$ & 5'-GGTGAGTTAGTGGAAGCAGTTGAC-3' \\
\hline SP157 & $3^{\prime} \mathrm{PPO}$ & 5'-GTCCCATTCAACTATCTTGGTAAG-3' \\
\hline Bar1 & BAR & 5'-AACCCACGTCATGCCAGTTCC-3' \\
\hline Bar2 & BAR & 5'-CGGCGGTCTGCACCATCGTC-3' \\
\hline
\end{tabular}

$1 \times$ protease inhibitor cocktail, complete, EDTA-free) was added to $50 \mathrm{mg}$ of tissue powder. Soluble protein was isolated by centrifugation at $4^{\circ} \mathrm{C}$. The protein concentration was determined using BIO-RAD protein assay reagent. Approximately $10 \mu \mathrm{g}$ of soluble proteins was separated on $10 \%$ SDS/PAGE. The proteins were semi-dry blotted onto BA85 nitrocellulose membrane (Whatman). Equal loading of the gels and quality of protein preparations were checked by staining extra sets of gels with Coomassie Brilliant Blue R250. Blots were blocked for $3 \mathrm{hr}$ in $5 \%$ nonfat dry milk in PBST $\left(10 \mathrm{mM} \mathrm{NaPO}_{4}, \mathrm{pH} 7.4 ; 120 \mathrm{mM} \mathrm{NaCl} ; 2.7 \mathrm{mM}\right.$ $\mathrm{KCl} ; 0.05 \% \mathrm{v} / \mathrm{v}$ Tween 20$)$ and incubated overnight at $4^{\circ} \mathrm{C}$ with peptide antibodies $(1: 1000)$ in the same buffer. Rabbit anti-Ku80 and anti-Ku70 polyclonal antibodies were raised against synthetic peptides corresponding to small domains of the proteins that exhibit sequence diversity and affinity chromatography purified (Eurogentec). The sequences of the synthetic peptides for AtKu80 and AtKu70 were $\mathrm{NH}_{2}$-LLRDKPSGSDDEDN-+C-CONH $\mathrm{H}_{2}$ and $\mathrm{NH}_{2}$ ELDPDDVFRDEDEDP-+C-CONH$H_{2}$, respectively, with a Cterminal coupling on the added cysteine. The blots were washed 4 times with PBST and incubated for $3 \mathrm{~h}$ with antirabbit HRP antibodies (1:7500) (Promega). The blots were again washed 4 times with PBST, and detection was performed using LumiGLO chemoluminescence detection kit (Cell Signalling).
2.5. Assays for Sensitivity to Bleomycin and Methyl Methane Sulfonate (MMS). Seeds of wild type, Atku70 and Atku80 were surface-sterilized and germinated on solid 1/2 MS medium. Four days after germination, the seedlings were transferred to liquid 1/2 MS medium without additions or 1/2 MS medium containing Bleocin (Calbiochem) or MMS (Sigma). The seedlings were scored after 2 weeks of growth. Fresh weight was determined by weighing the seedlings in batches of 20 in triplicate.

2.6. Comet Assay. DSBs were detected by a neutral comet assay as described previously [46] with minor modifications. Plant nuclei were embedded in $1 \%$ low melting point Ultrapure agarose-1000 (Invitrogen) to make mini gels on microscopic slides according to the protocol. Nuclei were subjected to lysis in high salt $(2.5 \mathrm{M} \mathrm{NaCl}, 10 \mathrm{mM}$ Tris- $\mathrm{HCl}, \mathrm{pH} 7.5$, $100 \mathrm{mM}$ EDTA) for $20 \mathrm{~min}$ at room temperature (N/N protocol). Equilibration for $3 \times 5 \mathrm{~min}$ in $1 \times \mathrm{TBE}$ buffer $(90 \mathrm{mM}$ Tris-borate, $2 \mathrm{mM}$ EDTA, $\mathrm{pH} 8.4$ ) on ice was followed by electrophoresis at $4^{\circ} \mathrm{C}$ in TBE buffer for $15 \mathrm{~min}$ at $30 \mathrm{~V}$ (1 V/cm), 15-17 mA. Dry agarose gels were stained with $15 \mu \mathrm{L}$ ethidium bromide $(5 \mu \mathrm{g} / \mathrm{mL})$ and immediately evaluated with a Zeiss Axioplan 2 imaging fluorescence microscope (Zeiss, Germany) using the DsRed channel (excitation at $510 \mathrm{~nm}$, emission at $595 \mathrm{~nm}$ ). Images of comets were captured at a 40-fold magnification by an AxioCam MRc5 
digital camera (Zeiss, Germany). The comet analysis was carried out by comet scoring software CometScore (TRITEK Corporation). The fraction of DNA in comet tails (\% DNA in tail) was used as a measure of DNA damage. The \% DNA in tail was measured at 3 time points: $0 \mathrm{~h}, 2 \mathrm{~h}, 24 \mathrm{~h}$ for $1 \mu \mathrm{g} / \mathrm{mL}$ bleomycin treatment and in the seedlings which had $24 \mathrm{~h}$ recovery in 1/2 MS after $24 \mathrm{~h}$ treatment. Measures included 4 independent gel replicas totaling about 100 comets analyzed per experimental point.

2.7. Isolation of Arabidopsis Mesophyll Protoplasts. Rosette leaves $(\sim 1 \mathrm{~g})$ from plants that were 3 to 5 weeks old were collected, rinsed with deionized water, and briefly dried. The leaves were cut into 0.5 to $1 \mathrm{~mm}$ strips with a razor blade, placed into a Petri dish containing $15 \mathrm{~mL}$ of filtersterilized enzyme solution $(1.5 \%(\mathrm{w} / \mathrm{v})$ cellulose R10, $0.4 \%$ (w/v) macerozyme R10, 0.4 M mannitol, $20 \mathrm{mM} \mathrm{KCl,} 20 \mathrm{mM}$ MES pH5.7, $10 \mathrm{mM} \mathrm{CaCl}_{2}$, and $\left.0.1 \%(\mathrm{w} / \mathrm{v}) \mathrm{BSA}\right)$ and 2 to $3 \mathrm{~h}$ incubated in the dark at $28^{\circ} \mathrm{C}$. Then the protoplasts were filtered with a $50 \mu \mathrm{m}$ mesh to remove the undigested material and transferred to a round bottom Falcon tube. The solution was centrifuged for $5 \mathrm{~min}$ at $600 \mathrm{rpm}$ to pellet the protoplasts. The supernatant which contained broken cells was discarded. The protoplasts were gently washed twice with $15 \mathrm{~mL}$ cold W5 solution (154 mM NaCl, $125 \mathrm{mM} \mathrm{CaCl}_{2}, 5 \mathrm{mM} \mathrm{KCl}$, $2 \mathrm{mM}$ MES $\mathrm{pH}$ 5.7) resuspended in cold W5 solution to a final concentration of $2 \times 10^{5}$ cells $/ \mathrm{mL}$, and kept on ice for $30 \mathrm{~min}$. Just before starting transfection, protoplasts were collected from the W5 solution by centrifugation and were resuspended to a density of $2 \times 10^{5}$ cells $/ \mathrm{mL}$ in $\mathrm{MMg}$ solution (0.4 M mannitol, $15 \mathrm{mM} \mathrm{MgCl}_{2}, 4 \mathrm{mM}$ MES pH5.7) at room-temperature.

2.8. In Vivo End-Joining Assay. Plasmid pART7-HA-GFP (S65T) was linearized by cleavage with BamHI. Fresh protoplasts prepared from leaves were transformed with either linear or circular plasmid DNA by the polyethylene glycol (PEG) transformation protocol [47]. In each experiment, $2 \times 10^{4}$ protoplasts were transformed with $2 \mu \mathrm{g}$ of plasmid. Recircularization of the linear plasmid in protoplasts by the NHEJ pathway was analyzed. DNA was extracted from protoplasts (at $0 \mathrm{~h}$ and $24 \mathrm{~h}$ ) and was used to quantify rejoining by Q-PCR. The DNA extraction protocol and the cycling parameters of Q-PCR were the same as mentioned above. Two pairs of primers were used: one pair (Q8 + Q9) was flanking both sites of the BamHI enzyme digestion site and the other pair $(\mathrm{Q} 10+\mathrm{Q} 11)$ was localized in GFP. When the plasmid is circular, both pairs will give products. When the plasmid is cleaved by BamHI, the first pair of primers will not give a product, whereas the second will still give products. The efficiency of end joining is presented by the ratio of PCR products using Q8 + Q9 primers and Q10 + Q11 primers in comparison with the controls. The value of the wild type was set on 1. Q-PCR was performed as three replicates and the assays were performed in triplicate.

2.9. Root Transformation. Root transformation was performed as described [48]. Sterile roots of 3-week-old wild type and mutants grown in agar were cut into segments and inoculated with Agrobacterium strain AT $\Delta v i r \mathrm{D} 2$ [49] with wild-type VirD2 on a plasmid harboring a $\beta$-glucuronidase(GUS-) expressing binary vector. After 2 days of cocultivation, excess of Agrobacterium cells was washed away. Some of the root segments were stained with 5-bromo-4-chloro-3indolyl $\beta$-D-glucuronide (X-Gluc) to measure the transient expression. GUS activity was determined as the number of blue spots per root segment. The residual root segments were plated on callus-induction medium containing kanamycin for 3-4 weeks to test callus formation as measure for TDNA integration [42]. Stable transformation was scored as infected root segments that produced any form of callus.

2.10. Floral Dip Transformation and Gene Targeting. Floral dip transformation was performed according to the procedure described by Clough and Bent [50]. The Agrobacterium strain AGL1 (pSDM3834) [45] was used for infection. Plasmid pSDM3834 is a pCambia 1200 derivative (hpt selection marker). Seeds were harvested from the dry plants after maturation and plated on solid MA medium without sucrose containing $15 \mu \mathrm{g} / \mathrm{mL}$ hygromycin, $100 \mu \mathrm{g} / \mathrm{mL}$ timentin (to kill Agrobacterium cells) and $100 \mathrm{mg} / \mathrm{mL}$ nystatin (to prevent growth of fungi). Hygromycin-resistant seedlings were scored 2 weeks after germination and transformation frequency was determined (50 seeds is $1 \mathrm{mg}$ ).

In order to test the frequency of gene targeting in the Atku70 and Atku80 mutants (ecotype Col-0), floral dip transformation was performed with Agrobacterium strain AGL1 (pSDM3900). Plasmid pSDM3900 is a pCambia 3200 derivative (phosphinothricin (ppt) selection marker), containing a truncated protoporphyrinogen oxidase $(P P O)$ gene isolated from Col-0 genomic DNA. Mutations were introduced in the coding region to obtain resistance to the herbicide butafenacil [10]. For gene targeting of the PPO gene in the Atku70 and Atmre11 mutants (ecotype ws) [36, 43] which have been isolated previously in our lab, floral dip transformation was performed with Agrobacterium strain LBA1115(pSDM1502) (original name of the plasmid is pSDM) [10]. About 1 gram of seeds was plated on solid MA medium without sucrose containing $15 \mu \mathrm{g} / \mathrm{mL} \mathrm{ppt}$, $100 \mu \mathrm{g} / \mathrm{mL}$ timentin and $100 \mu \mathrm{g} / \mathrm{mL}$ nystatin to determine the transformation frequency. The rest of the seeds were all sowed on solid MA medium without sucrose containing $50 \mu \mathrm{M}$ butafenacil, $100 \mu \mathrm{g} / \mathrm{mL}$ timentin and $100 \mu \mathrm{g} / \mathrm{mL}$ nystatin to identify gene targeting events.

\section{Results}

3.1. Isolation and Characterization of T-DNA Insertion Mutants. In order to study and compare the roles of AtKu70 and AtKu80 in Agrobacterium-mediated transformation and gene targeting in Arabidopsis, homozygous T-DNA insertion mutants of AtKu70 and AtKu80 (ecotype Col-0) were isolated and characterized. Using T-DNA-specific primers from the left border in combination with gene-specific primers (Table 1) flanking the insertion site, heterozygous and homozygous mutants were identified (results not shown). No PCR products were obtained for homozygous mutants by using two gene-specific primers, because the PCR products 


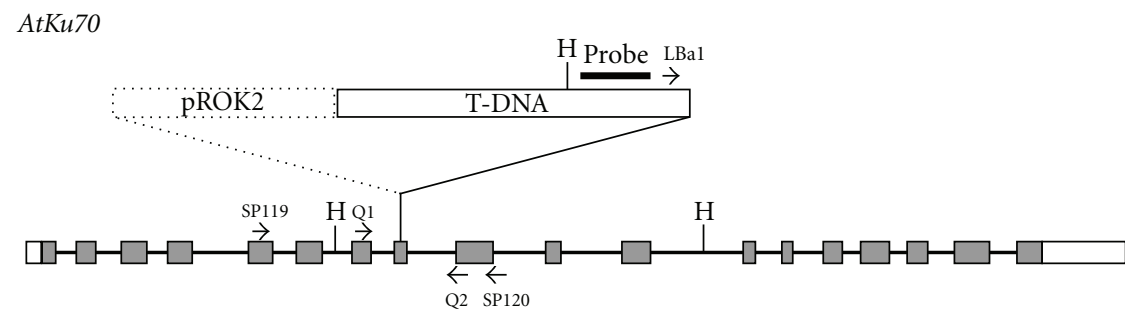

Left border-genomic DNA junction: CGTCAATTTGTT GCAATCTCTATTTGTTTAACTTAATCACAATTGGATT

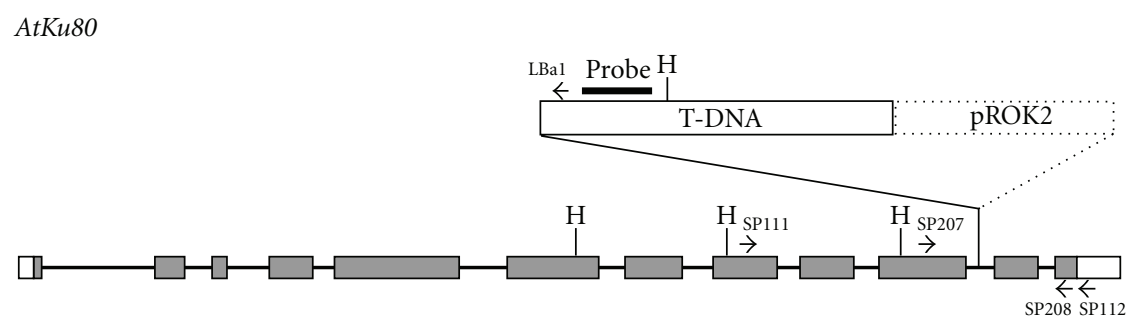

Genomic DNA-left border junction:

TGGATTTATAAGTTGTGACCCCCGCCGATGACGCGGGACAATCTGTTATA

(a)

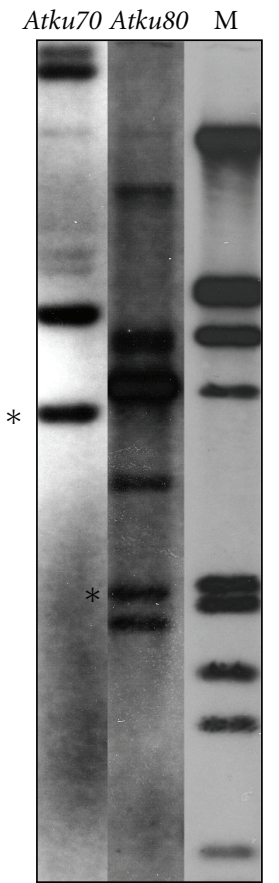

(b)

FIgURE 1: Molecular analysis of the T-DNA insertion lines. (a) Genomic organization of the AtKu70 and AtKu80 loci in the Atku70 and Atku 80 mutants. Inserted T-DNA and pROK2 vector part of the binary vector are indicated. Exons are shown as grey boxes, $3^{\prime}$ and $5^{\prime}$ UTRs are shown as white boxes, and introns are shown as lines. The primers used for genotyping and Q-RT-PCR analysis are indicated. The probe and the restriction enzyme digestion sites ( $\mathrm{H}$ for HindIII) used for Southern blot analysis are also indicated. The sequence of the T-DNA-genomic DNA junctions are shown: genomic DNA (italic) in dark grey boxes, T-DNA insertions in light grey boxes and filler DNA not boxed. (b) Southern blot analysis of the Atku70 and Atku80 mutants. DNA was digested with HindIII and separated in $0.7 \%$ agarose gel along a dig-labeled Lambda EcoRI/HindIII marker (lane M), blotted, and hybridized with a DIG-labelling T-DNA probe. The bands with the expected size are indicated with an asterisk.

in the mutant would be $>10 \mathrm{~kb}$ in size and would not be detectable. The insertion point of the T-DNA left border (LB) was mapped by sequencing of the PCR products generated by LBa1 in combination with one of the gene-specific primers. For both $A t k u 80$ and $A t k u 70$, no PCR products were obtained using the $\mathrm{RB}$ primer or the $\mathrm{LB}$ primer in combination with the other gene-specific primer, but PCR products $(600 \mathrm{bp})$ were amplified by using primers spanning the RB/vector junction (SP205 and SP206). That indicated that the RB was integrated with extra vector pBin-ROK2 DNA. Therefore, the RB integration site could not be mapped in the Atku80 and Atku70 mutants. A detailed characterization of the TDNA insertion lines is shown in Figure 1(a). Sequences of the border fragments showed that the LB end of the T-DNA in Atku 70 was integrated into exon 8 and had 28 bps filler DNA. The LB end of the T-DNA in Atku80 was integrated into intron 10, had lost 7 base pairs (bps), and had incorporated 43 bps filler DNA. The genomic DNA was digested by HindIII for Southern blotting (Figure 1(b)). Bands with the expected sizes were detected (Atku70: $3.2 \mathrm{~kb} ;$ Atku80: $2.0 \mathrm{~kb}$ ).
In both mutants extra bands were detected, indicating that additional T-DNAs were present. The thick band in the Atku80 lane could indicate the presence of several copies of inverted repeated T-DNAs, which would result in a band of about $3.6 \mathrm{~kb}$.

We did not observe any dwarf or sterile phenotype in these Arabidopsis mutant lines. Also no obvious differences in growth, flowering, or senescence were observed between mutants and wild-type plants. A somewhat delayed germination was the only phenotype found in the Atku 80 mutant, in which it differed from the wild type. In order to confirm that the mutants were indeed homozygous, Q-RT-PCR analysis was performed for all T-DNA insertion lines using primers flanking the insertion site. This resulted in a product for each gene in the wild type, but not in the corresponding TDNA insertion mutant (Figure 2), showing that the mutants were truly homozygous. The expression level of AtKu70 was increased in the Atku80 mutants and vice versa, and the AtLig4 expression was also increased in both mutants, suggesting some form of feedback regulation. 


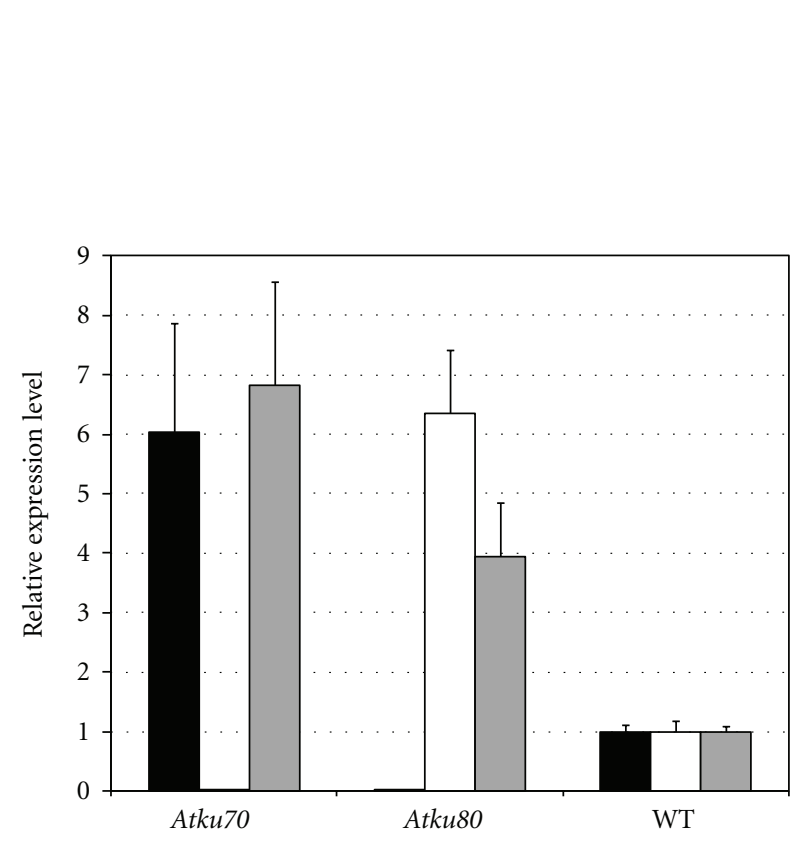

(a)
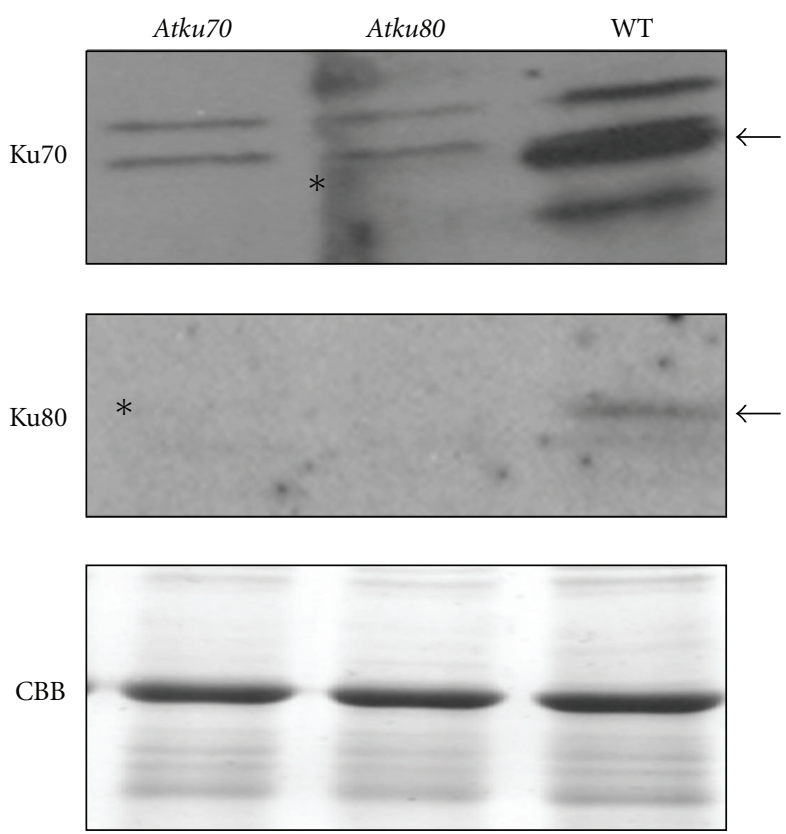

(b)

Figure 2: Q-RT-PCR and Western blot analysis. (a) RNA expression of the NHEJ genes AtKu80 (black bars), AtKu70 (white bars) and AtLig4 (grey bars) as determined by Q-RT-PCR, in the Atku70 and Atku80 mutants and wild-type (WT) plants. All sample values were normalized to Roc1 values and were obtained in triplicate. The values of the wild type were set on 1. (b) Western blot analysis of leaf protein samples from the Atku70 and Atku80 mutants and wild-type (WT) plants using anti-AtKu70 antibody (upper panel) and anti-AtKu80 antibody (middle panel), detecting AtKu70 and AtKu80, respectively (arrows). The weak signals of residual AtKu70 in the Atku80 mutant and residual AtKu80 in the Atku70 mutant are indicated with an asterisk. Similar amounts $(10 \mu \mathrm{g})$ of soluble leaf protein were loaded in each lane as shown by the Coomassie-stained gel (lower panel).

Western blot analysis was performed on protein extracts from Atku70, Atku80, and wild-type plants using polyclonal peptide antibodies raised against AtKu70 or AtKu80. A CBBstained replica gel showed that similar amounts of proteins were loaded in each lane. A $70 \mathrm{kD}$ band, the predicted size of the AtKu70 protein, was present in wild-type plants, but not detectable in the Atku70 mutant with anti-Ku70 antibodies, and the signal was very weak in the Atku80 mutant (Figure 2). An $80 \mathrm{kD}$ band, the predicted size of the AtKu80, was present in wild-type plants, but not detectable in the Atku80 mutant with anti-Ku80 antibodies. A very weak signal was found in the Atku70 mutant (better visible on the original X-ray film). Apparently, the loss of one of the $\mathrm{Ku}$ subunits resulted in a significant decrease in the amount of the other subunit according to the western blot data. This indicated that heterodimerization of AtKu70 and AtKu80 is required for the stabilization of the Ku proteins in plants as was previously shown in mammals $[22,51]$.

3.2. Sensitivity to Genotoxic Agents. Mammalian cell lines, yeast strains, and Arabidopsis mutants lacking Ku80 or Ku70 have defects in DSB repair and are sensitive to DNA-damaging agents. We tested whether disruption of these genes in our mutants also affected sensitivity of the plants to DNAdamaging agents by comparing growth of the wild type, and these NHEJ mutants during exposure to bleomycin or MMS. Bleomycin is a radiomimetic chemical that induces
DNA double-strand breaks (DSBs) [52]. MMS is a monofunctional alkylating agent that induces $N$-alkyl lesions and DNA single-strand breaks (SSBs) that can be converted into DSBs during replication [53]. As expected, both mutants were hypersensitive to bleomycin and the Atku70 mutant seemed also somewhat sensitive to MMS (Figure 3(a)). To quantify this, the fresh weight of seedlings was determined after 2 weeks of continuous treatment. Compared with wildtype seedlings, NHEJ-mutated seedlings showed growth retardation in the presence of these two genotoxic agents (Figure 3(b)). In the presence of bleomycin, the fresh weight of Atku80 was 2-fold less than that of the wild type and the fresh weight of Atku70 was about 4-fold less than that of the wild type. The fresh weight of all seedlings was lower after growth in the presence of MMS compared to bleomycin. According to the student's $t$-test, the Atku70 mutant had a significantly lower weight than the wild type grown in the presence of MMS, but there was no significant difference between the wild type and the Atku80 mutant. These data corroborated that AtKu80 and AtKu70 are main components of the DSB repair machinery and that the Atku70 mutants are more sensitive to genotoxic agents than the Atku80 mutant.

In order to quantify the DNA damage in these mutants, comet assays were performed. For each treatment, around 100 randomly chosen nuclei were analyzed by using CometScore. The results are shown as \% DNA in the tail, which is related to the amount of DNA damage (Figure 4(a)). 


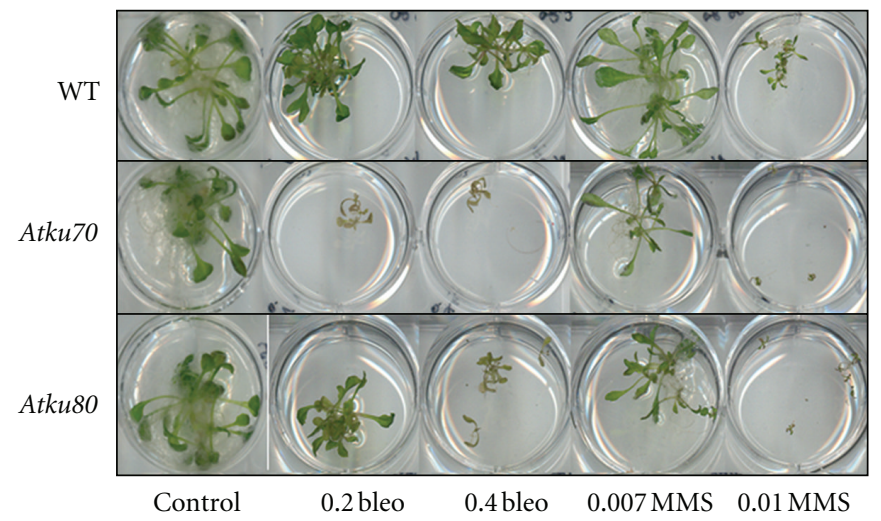

(a)

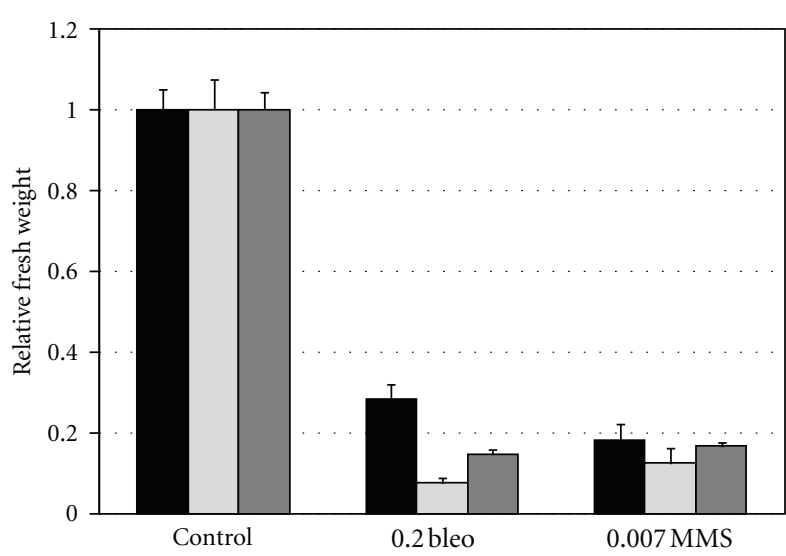

(b)

FIgure 3: Hypersensitivity of Atku70 and Atku80 plants to DNA-damaging treatments. (a) Phenotypes of wild-type (WT) plants and Atku70 and Atku80 mutants after bleomycin or MMS treatment. Four-day-old seedlings were transferred to liquid $1 / 2 \mathrm{MS}$ medium (control) or 1/2MS medium containing different concentrations of bleomycin (bleo) or MMS and were scored 2 weeks after germination. (b) Fresh weight of 2-week-old wild-type plants (black bars) and Atku70 (light grey bars) and Atku80 (dark grey bars) mutants treated with $0.2 \mu \mathrm{g} / \mathrm{mL}$ bleomycin or $0.007 \%$ MMS. For each treatment 20 seedlings were weighed in triplicate. Fresh weight of the plants grown for 2 weeks without bleomycin or MMS was set at 1.

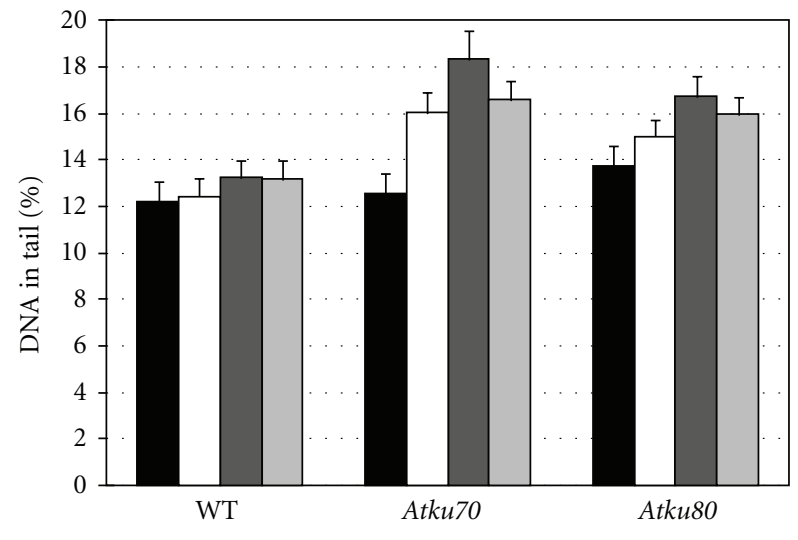

(a)

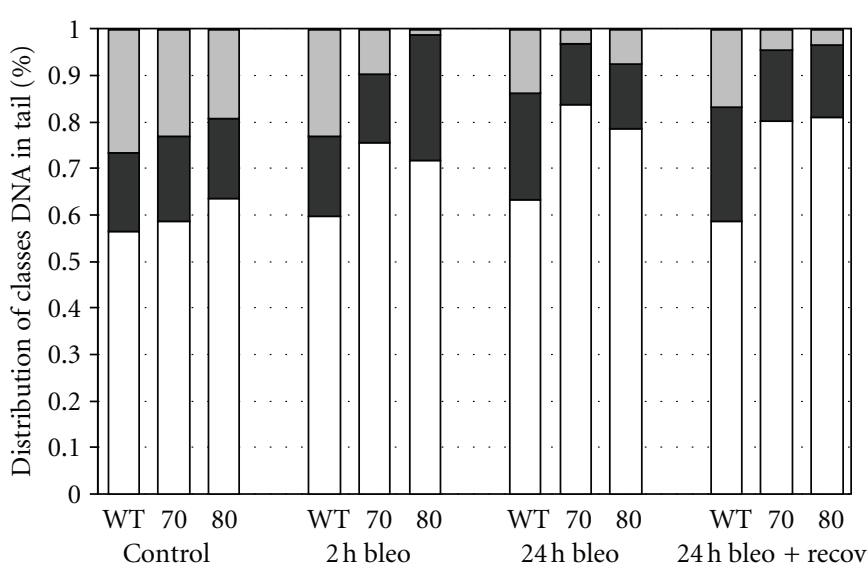

(b)

FIgure 4: Comet assay. (a) The fraction of DNA in comet tails (\%DNA in tail) was used as a measure of DNA damage in wild-type plants (WT), Atku70 and Atku80 mutants: no treatment (black bars); $2 \mathrm{~h}$ bleomycin treatment (white bars); $24 \mathrm{~h}$ bleomycin treatment (dark grey bars); $24 \mathrm{~h}$ bleomycin treatment followed by $24 \mathrm{~h}$ recovery (light grey bars). For each treatment, around 100 nuclei were analyzed. (b) According to the value of $\%$ DNA in tail, nuclei from the plants after the treatments indicated in (a) were divided into three groups: $<5 \%$ damage (light grey bars); 5-10\% damage (dark grey bars); $>10 \%$ damage (white bars).

The nuclei were also divided into three groups according to the $\%$ DNA in the tail $(<5 \%, 5 \sim 10 \%,>10 \%)$ (Figure $4(\mathrm{~b})$ ). The plants were treated with bleomycin for $2 \mathrm{~h}, 24 \mathrm{~h}$, and $24 \mathrm{~h}$ followed by $24 \mathrm{~h}$ recovery and compared with the situation before treatment (control). The results showed that the genomic DNA of the Atku80 mutant was already more damaged even before treatment with bleomycin. After $2 \mathrm{~h}$ treatment, more DNA damage was seen in the nuclei of both the Atku80 and Atku70 mutants than in the wild type, which was further increased after $24 \mathrm{~h}$ treatment with bleomycin. This indicated that the genome of the Atku80 and Atku70 mutant was damaged quicker and thus that repair was slower than in the wild type. Interestingly, the NHEJ mutants had less
DNA damage after $24 \mathrm{~h}$ recovery compared to the situation before recovery, though they still had more DNA damage than the wild type. This showed that a slow back-up DNA repair pathway must exist for repair of DNA damage in the NHEJ mutant plants.

3.3. In Vivo End-Joining Activity. To directly test the function of AtKu70 and AtKu80 in end-joining, we used an in vivo plasmid rejoining assay to quantify the capacity of protoplasts to repair restriction-enzyme-generated DSBs. To this end, we transformed protoplasts from leaves with circular (control) or BamHI-linearized plasmid DNA (Figure 5(a)). BamHI digests the plasmid DNA in the N-terminal part of 


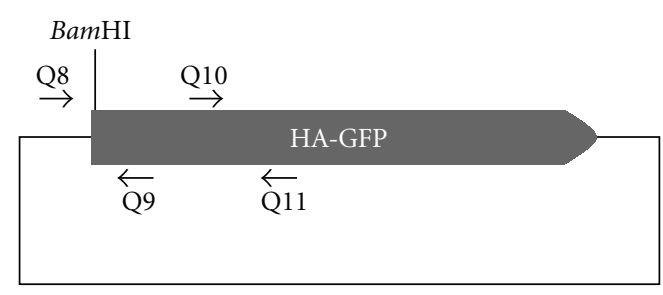

(a)

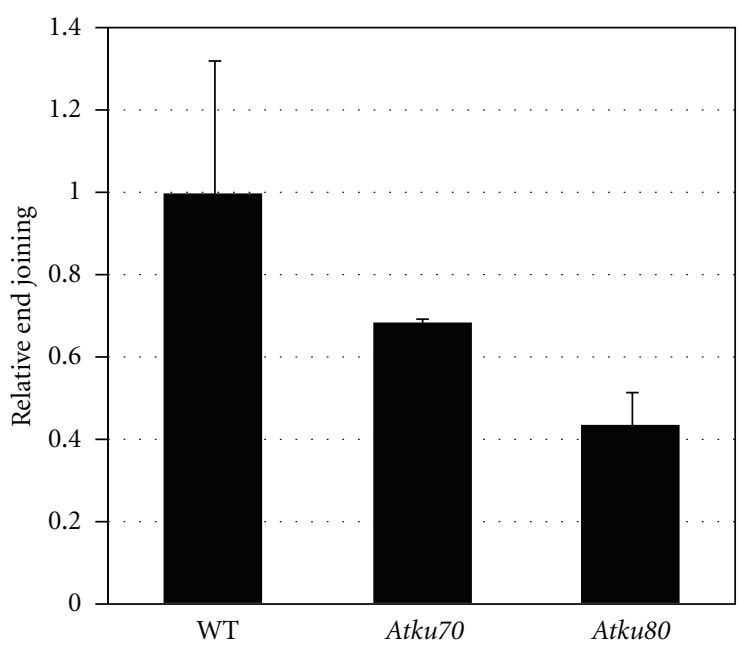

(b)

Figure 5: Plasmid end-joining assay. (a) Plasmid pART7-HA-GFP was digested with BamHI and transfected into Arabidopsis protoplasts. Circularization was determined with QPCR using the primers Q8 and Q9 compared to the product with primers Q10 and Q11. (b) Values of end-joining in the mutants are given relative to those of the wild type.

the GFP coding sequence. Rejoining of linear plasmid in vivo will result in GFP expression. GFP fluorescence was indeed detected in the wild-type protoplasts which were transformed with linearized plasmid, but it was difficult to quantify the difference of GFP expression between the wild type and the mutants under the fluorescence microscope. Therefore, we analyzed the rejoining efficiency by Q-PCR, using primers around the BamHI site compared to primers in the GFP coding region (see Supplementary Table S1 available online at doi:10.1155/2012/989272). The results showed that the rejoining efficiencies were reduced by half in the Atku70 and Atku80 mutants compared with the wild type (Figure 5(b)). This proved directly that AtKu70 and AtKu80 are involved in NHEJ.

3.4. T-DNA Integration. To test whether the AtKu70 and AtKu80 genes are required for T-DNA integration in plants, we compared T-DNA integration in these NHEJ mutants and wild-type plants using two different Agrobacterium transformation assays.

First, in vitro root transformation was performed, using a binary vector with both a GUS gene and the NptII gene. The transient GUS activity was determined as the number of blue spots per root segment. T-DNA integration was scored as the percentage of infected root segments that produced any form of callus on selective callus-inducing medium. In principle, for each plant line, the transient GUS activity, which reflects expression of nonintegrated T-DNA, should be at the same level, whereas callus formation theoretically could be reduced in mutants affected in T-DNA integration. Our results showed no significant difference, neither in transient GUS expression nor in callus formation between the NHEJ mutants and the wild type (data not shown).

Secondly, we transformed germline cells using the floral dip method. The transformation frequency was determined as the number of hygromycin-resistant seedlings per total number of plated seeds. In this assay, the transformation frequency of $A t k u 80$ and $A t k u 70$ plants turned out to be reduced significantly to 20 percent of the wild-type transformation frequency (Table 2). Besides the Col-0 mutants characterized here, our previously isolated Atku70 and Atmre 11 mutants of the ecotype ws $[36,43]$ were also used. Both mutants also showed similar reduced transformation frequencies of about 20 percent. This indicated that AtKu80, AtKu70 and AtMre11 are required for efficient Agrobacterium T-DNA integration in plant germline cells.

3.5. Gene Targeting. Since GT was significantly increased in NHEJ mutants in yeast and fungi [3-9], our NHEJ mutants of Arabidopsis thaliana were used to study their GT frequency. The plants were transformed using a repair T-DNA with an incomplete mutated $P P O$ gene with homology to the plant genome (Figure 6(a)) through Agrobacterium floral dip transformation. If the targeted endogenous $P P O$ gene is replaced by the mutated $P P O$ of the T-DNA, the plants become resistant to butafenacil. If there are T-DNAs randomly inserted in other loci of the genome, the plants will become resistant to phosphinothricin (ppt).

First, $1 \mathrm{~g}$ of seeds of the Atku70 (Col-0 and ws), Atku80 (Col-0), and Atmre11 (ws) mutants and corresponding wildtype plants from the floral dip transformation was used to determine the transformation frequency by plating on $\mathrm{ppt}$ medium (Table 2). In all 4 mutants the frequencies were lower compared to the wild type as already described above. The remaining seeds were plated with selection for butafenacil resistance. The theoretical number of transformants in these seed batches was calculated from the transformation frequency (Table 2).

Two butafenacil-resistant plants were found in 2600 transformants of the wild type (ecotype Col-0). PCR analysis 

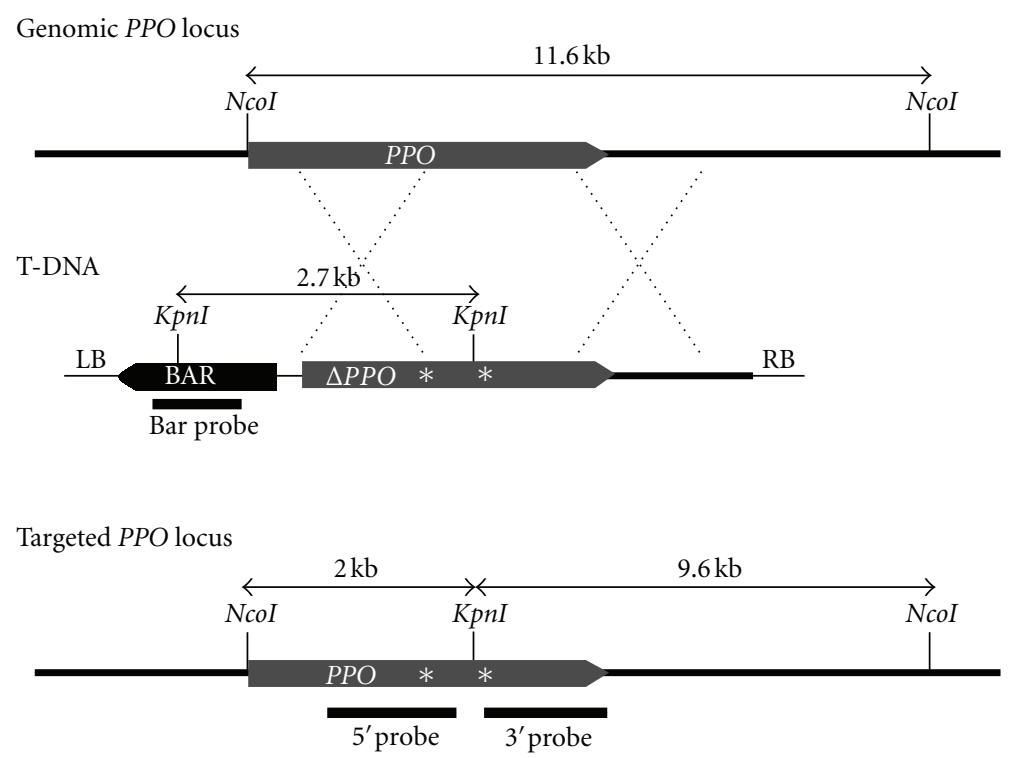

(a)

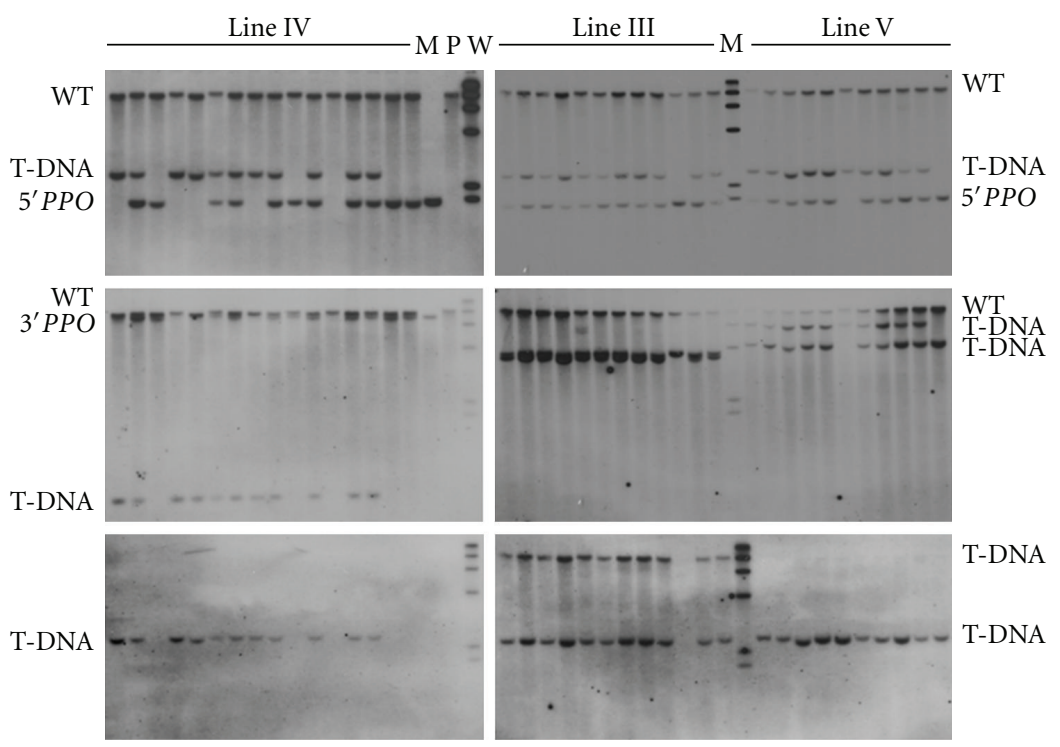

(b)

Figure 6: Gene targeting of the Arabidopsis PPO locus. (a) Schematic representation of gene targeting at the PPO locus. The grey box marked $P P O$ represents the $P P O$ coding region, and the thick black lines represent flanking plant genomic DNA. The repair T-DNA [10] (LB for left border and RB for right border) contains a BAR (black box marked BAR) selection marker linked to the $5^{\prime}$ truncated $\triangle P P O$ gene (grey box marked $\triangle P P O)$. The thin lines indicate the T-DNA sequences. The two mutations conferring butafenacil resistance are indicated by asterisks. The probes and the restriction enzyme digestion sites used for Southern blot analysis and the sizes of expected bands are shown. (b) Southern blotting of progeny plants of three butafenacil resistant lines (III, IV and V). DNA was digested with NcoI and KpnI and separated in $0.7 \%$ agarose gel along a positive gene-targeted sample (lane P), a wild-type sample (lane W) and dig-labeled Lambda HindIII marker (lane M), blotted and hybridized with a DIG-labelled 5' $P P O$ probe (upper panels), 3' $P P O$ probe (middle panels) and a BAR probe (lower panels). The bands with sizes expected after gene targeting are indicated with $3^{\prime} P P O$ and 5'PPO. The wild-type PPO band (WT) and bands representing additional T-DNAs are also shown.

and Southern blotting showed that both plants represent true gene targeting (TGT) events (data not shown). One of these plants was also ppt resistant, indicating the presence of extra T-DNA copies. There were no GT events found in around 1000 transformants of the Atku70 and Atku80 (ecotype Col-0) mutants (Table 2), indicating that the gene targeting frequency was not significantly increased in those mutants compared with the wild type.

Subsequently, the ws wild type and mutants were used for a GT experiment. In about $10^{4}$ wild-type transformants, no GT event was observed. Since the transformation frequency of $A t k u 70$ (ecotype ws) was rather low, only 
TABLE 2: Transformation frequencies and gene targeting events in NHEJ mutants.

\begin{tabular}{|c|c|c|c|c|}
\hline Plant line & Plasmid & Rel. transf. freq. & Transformants & GT events \\
\hline Col-0 & pSDM3834 & 100 & & \\
\hline Atku70 & pSDM3834 & 24 & & \\
\hline Atku 80 & pSDM3834 & 24 & & \\
\hline Col-0 & pSDM3900 & 100 & 2600 & 2 \\
\hline Atku70 & pSDM3900 & 25 & 1086 & 0 \\
\hline Atku80 & pSDM3900 & 24 & 1143 & 0 \\
\hline ws & pSDM1502 & 100 & 10927 & 0 \\
\hline Atku70 & pSDM1502 & 23 & 980 & 0 \\
\hline Atmre11 & pSDM1502 & 21 & 3625 & 3 \\
\hline
\end{tabular}

about 1000 transformants were obtained and no GT events were observed. However, there were 3 butafenacil-resistant plants found in 3625 transformants of the Atmre11 mutant (ecotype ws). Therefore, the frequency of gene targeting seems to be increased at least 10-fold in the Atmre11 mutant compared with that in the ws wild type. Initial PCR analysis showed that GT had occurred in these plants (results not shown). The apparent difference in GT frequencies found between the ecotypes Col-0 (2 in 2600) and ws (none in $10^{4}$ ) may be caused by ecotype differences, but also by the different Agrobacterium strains and binary vectors that were used for the GT experiments.

The GT plants were further analyzed by Southern blotting. The genomic DNA of progeny plants of the 3 plant lines was digested by KpnI and NcoI for Southern blotting (Figure 6). With the 5'PPO probe and the $3^{\prime} P P O$ probe, a band of $11.6 \mathrm{~kb}$ was detected for the wild-type allele in all lanes. In most progeny plants of all three lines, a band of $2 \mathrm{~kb}$ representing the gene targeting allele was detected with the $5^{\prime} P P O$ probe. With the $3^{\prime} P P O$ probe, a band of $9.6 \mathrm{~kb}$ representing the gene targeting allele was only detected in line IV. The results showed that the plant lines III and V of Atmre11 represented ectopic gene targeting (EGT) events, whereas plant IV represented a true gene targeting (TGT) event. All three plant lines had extra bands with the $3^{\prime} P P O$, the $5^{\prime} P P O$, and the BAR probe, and moreover, they were ppt resistant, suggesting that they all contained extra T-DNA insertions.

\section{Discussion}

Here, we isolated and characterized two Arabidopsis thaliana Col-0 NHEJ mutants in which AtKu70 or AtKu80 was inactivated through a T-DNA insertion. Homozygous mutants did not show any obvious growth phenotype or sterility, like the ws mutants described in previous publications [36-41], indicating that in this respect there are no differences between ecotypes. These mutants were hypersensitive to the DNAdamaging agents, bleomycin and MMS, as was previously shown for Atku70 and Atku80 mutants of the ws ecotypes [36-41]. Atku70 and Atku80 seedlings seem to be more sensitive to bleomycin than to MMS compared to wild-type plants. Bleomycin will induce predominantly DSBs, whereas MMS will cause SSBs, which may be converted to DSBs during DNA replication in S phase [54]. This indicated that AtKu70 and AtKu80 play a more important role in DSBs repair than SSBs repair in plants, like in animals and fungi.

We quantified the DNA-damage with comet assays and showed that the mutants have more DNA damage even in the absence of DNA damaging agents and repair is slower than in the wild type. The opposite was found for one of the previously described ws Atku80 mutants [55]; DNA repair in this mutant was faster than in the wild type. End-joining assays showed that AtKu70 and AtKu80 are directly involved in DNA repair, as was shown previously for the above mentioned Atku80 (ws) mutant [38].

Mice lacking Ku70 or Ku80 are fertile, but they show growth retardation and have immuno-deficiencies due to defects in $\mathrm{V}(\mathrm{D}) \mathrm{J}$ recombination [56-58]. In mice, the Ku70 and Ku80 are involved in DSB repair, but they may have additional functions that are necessary for normal development and may be involved in cell growth, DNA replication, G1$\mathrm{S}$ transition, and Bax-mediated apoptosis in mammals [5962]. In plants and lower eukaryotes, Ku70 and Ku80 may lack these functions essential for normal development under standard growth conditions and therefore show no phenotype under these conditions.

It has been reported that $\mathrm{Ku} 80$ and $\mathrm{Ku} 70$ need to be heterodimerized as a ring to bind DNA ends and repair DNA damage $[28,63]$. We found that dimerization is necessary for stabilization of the heterodimer. Therefore, the Atku80 and $A t k u 70$ mutants are expected to have similar phenotypes. However, Atku70 plants seem to be more sensitive to bleomycin than Atku80 plants (Figure 3). It was also reported that there are some differences in the phenotypes of $K u>0$ and Ku80 knock-out mice [64]. However, here deleting Ku70 had milder effects than deleting Ku80 in p53-mutant mice. The authors speculated that Ku80 may function outside the $\mathrm{Ku}$ heterodimer to suppress cancer caused by translocations in mice [65]. The difference between Atku70 and Atku80 mutant plants may suggest that residual AtKu70 present in the Atku 80 mutant by itself can help plants to cope with low levels of genotoxic stress. Since the T-DNA is inserted in the very end of the AtKu80 gene in the Atku80 mutant, it is also possible that a small amount of truncated AtKu80 remaining in the Atku80 mutant heterodimerized with AtKu70 to promote DNA end-joining. We investigated the RNA expression of AtKu80 in the Atku 80 mutant by RT-PCR 
using primers located in the $\mathrm{N}$-terminal part of the coding region before the T-DNA insertion site. The results showed that there are products detectable (data not shown). Possibly a truncated protein, which still may retain partial function, is produced at low level causing the Atku80 mutant to better stand DNA damage stress than the Atku70 mutant. Western blot was performed using the antibody that in principle could detect a C-terminal-truncated AtKu80 protein. But no Ku80-related bands with a smaller MW were detectable on the western blot, indicating that no truncated protein was produced or that the amount was too low for detection. Alternatively, the presence of the complete or partial mRNAs may have a regulatory role in the plant cell.

In yeast and fungi non-homologous T-DNA is integrated by NHEJ [1] and preventing NHEJ opens the route to efficient gene targeting [6]. The results obtained in Arabidopsis so far were variable. Using floral dip transformation, plants with one Atku80 (ws) mutant allele showed reduced T-DNA integration frequencies [37] whereas plants with another Atku80 (ws) mutant allele showed enhanced transformation [38]. In root transformation assays, however, this latter mutant was strongly affected in T-DNA integration [42]. This suggested that perhaps the NHEJ genes have a more prominent role in root transformation. In this paper, we used a new set of NHEJ (Col-0) mutants to compare the transformation efficiency in both root and floral dip transformations. We found reduced transformation after floral dip in the $\mathrm{Ku}$ mutants of both ws and Col-0 ecotypes. However, no reduction in transformation was seen after root transformation. A possible explanation of our results could be that B-NHEJ is more active in roots compared to floral tissue, masking the loss of C-NHEJ in Atku80 roots. Also, C-NHEJ could be a minor DNA repair pathway in roots compared to floral tissue. However, expression levels of AtKu70 and AtKu80 are fairly similar in all plant tissues as found in microarray data in the Genevestigator expression tool [66] (results not shown), indicating that at least on the expression level CNHEJ is present throughout the plant at the same level. It is also possible that transformed calli induced on the wound sites after root transformation are derived from multiple cells and that high transformation frequencies mask differences between wild-type plants and mutants in our experiments.

Three Atmre11 (Col-0) mutants were also ordered by us from the Salk T-DNA collection (Atmre11c-1: SALK_028450, Atmre11c-2: SALK_0554418, Atmre11c-3: SALK_067823). No homozygous progeny was obtained for the Atmre11c-2 mutant. The homozygous Atmre11c-1 and Atmre11c-3 mutants were dwarf and sterile (data not shown), similar to the phenotype of the Atmre-1 (ws) mutant described previously by us [43]. Complete absence of AtMre11 will probably inactivate most if not all DNA repair pathways including HR. Since no seeds were obtained from these Atmrel1 mutants (ecotype Col-0), no further analysis was done with these mutants. Therefore, the mild Atmre11-2 (ws) mutant that was previously isolated was used for gene targeting experiments. This resulted in a number of GT events as opposed to the wild type, indicating that the GT frequency is increased in this Atmre11 mutant. Mre11 is involved in multiple DNA repair pathways, including B-NHEJ [67]. Probably, partial inactivation of AtMre11 has a detectable effect on the GT frequency since multiple NHEJ pathways are affected, whereas in the Atku70 and Atku80 mutants B-NHEJ is still active.

The transformation frequency using the floral dip method dropped significantly in our Atku70, Atku80 and Atmre11 Arabidopsis mutants. However, in these NHEJ mutants, integration of the T-DNA still occurred mostly at random positions. These results showed that alternative (back-up) endjoining pathways must be functional in the NHEJ mutants. In mammals back-up (B)-NHEJ pathways have been identified, which become active in the absence of the core NHEJ factors, such as $\mathrm{Ku}$ and Lig4 [68]. We will explore B-NHEJ pathways in Arabidopsis further in the future.

\section{Acknowledgments}

The authors thank J. Paszkowski for the SDM plasmid (our lab collection number pSDM1500) and the PPO-positivetarget line and Amke den Dulk-Ras, Vanessa Costa, Joy Ramdjielal, and Tiia Husso for their technical assistance with the characterization of the mutants and selection of butafenacil-resistant plants. This work was financially supported by the Chinese Scholarship Council (CSC) (QJ), EU Plantrec (QLRT-2000-01397) (PB), EU Recbreed (KBBE2008-227190) (SdP), and the Dutch Technology Foundation Stichting Toegepaste Wetenschappen (STW) (LGC5583) (SdP).

\section{References}

[1] H. van Attikum, P. Bundock, and P. J. J. Hooykaas, "Non-homologous end-joining proteins are required for Agrobacterium T-DNA integration," EMBO Journal, vol. 20, no. 22, pp. 65506558, 2001.

[2] K. I. Yano, K. Morotomi-Yano, N. Adachi, and H. Akiyama, "Molecular mechanism of protein assembly on dna doublestrand breaks in the non-homologous end-joining pathway," Journal of Radiation Research, vol. 50, no. 2, pp. 97-108, 2009.

[3] H. van Attikum and P. J. J. Hooykaas, "Genetic requirements for the targeted integration of Agrobacterium T-DNA in Saccharomyces cerevisiae," Nucleic Acids Research, vol. 31, no. 3, pp. 826-832, 2003.

[4] V. Bhadauria, S. Banniza, Y. Wei, and Y. L. Peng, "Reverse genetics for functional genomics of phytopathogenic fungi and oomycetes," Comparative and Functional Genomics, vol. 2009, Article ID 380719, 2009.

[5] P. de Boer, J. Bastiaans, H. Touw et al., "Highly efficient gene targeting in Penicillium chrysogenum using the bi-partite approach in $\triangle$ lig4 or $\triangle k u 70$ mutants," Fungal Genetics and Biology, vol. 47, no. 10, pp. 839-846, 2010.

[6] R. Kooistra, P. J. J. Hooykaas, and H. Y. Steensma, "Efficient gene targeting in Kluyveromyces lactis," Yeast, vol. 21, no. 9, pp. 781-792, 2004.

[7] V. Meyer, M. Arentshorst, A. El-Ghezal et al., "Highly efficient gene targeting in the Aspergillus niger kusA mutant," Journal of Biotechnology, vol. 128, no. 4, pp. 770-775, 2007.

[8] J. B. Nielsen, M. L. Nielsen, and U. H. Mortensen, “Transient disruption of non-homologous end-joining facilitates targeted genome manipulations in the filamentous fungus Aspergillus 
nidulans," Fungal Genetics and Biology, vol. 45, no. 3, pp. 165170, 2008.

[9] Y. Ninomiya, K. Suzuki, C. Ishii, and H. Inoue, "Highly efficient gene replacements in Neurospora strains deficient for nonhomologous end-joining," Proceedings of the National Academy of Sciences of the United States of America, vol. 101, no. 33, pp. 12248-12253, 2004.

[10] M. Hanin, S. Volrath, A. Bogucki, M. Briker, E. Ward, and J. Paszkowski, "Gene targeting in Arabidopsis," Plant Journal, vol. 28, no. 6, pp. 671-677, 2001.

[11] U. Halfter, P. C. Morris, and L. Willmitzer, "Gene targeting in Arabidopsis thaliana," Molecular and General Genetics, vol. 231, no. 2, pp. 186-193, 1992.

[12] M. Hrouda and J. Paszkowski, "High fidelity extrachromosomal recombination and gene targeting in plants," Molecular and General Genetics, vol. 243, no. 1, pp. 106-111, 1994.

[13] K. Y. Lee, P. Lund, K. Lowe, and P. Dunsmuir, "Homologous recombination in plant cells after Agrobacterium-mediated transformation," Plant Cell, vol. 2, no. 5, pp. 415-425, 1990.

[14] Z.-H. Miao and E. Lam, "Targeted disruption of the TGA3 locus in Arabidopsis thaliana," Plant Journal, vol. 7, no. 2, pp. 359-365, 1995.

[15] R. Offringa, M. J. de Groot, H. J. Haagsman, M. P. Does, P. J. M. van den Elzen, and P. J. J. Hooykaas, "Extrachromosomal homologous recombination and gene targeting in plant cells after Agrobacterium mediated transformation," EMBO Journal, vol. 9, no. 10, pp. 3077-3084, 1990.

[16] J. Paszkowski, M. Baur, A. Bogucki, and I. Potrykus, "Gene targeting in plants," EMBO Journal, vol. 7, pp. 4021-4026, 1988.

[17] E. Risseeuw, R. Offringa, M. E. I. Franke-van Dijk, and P. J. J. Hooykaas, "Targeted recombination in plants using Agrobacterium coincides with additional rearrangements at the target locus," Plant Journal, vol. 7, no. 1, pp. 109-119, 1995.

[18] S. E. Critchlow and S. P. Jackson, "DNA end-joining: from yeast to man," Trends in Biochemical Sciences, vol. 23, no. 10, pp. 394-398, 1998.

[19] M. R. Lieber, "The mechanism of human nonhomologous DNA End joining," Journal of Biological Chemistry, vol. 283, no. 1, pp. 1-5, 2008.

[20] M. Koike, "Dimerization, translocation and localization of Ku70 and Ku80 proteins," Journal of Radiation Research, vol. 43, no. 3, pp. 223-236, 2002.

[21] C. Muller, J. Paupert, S. Monferran, and B. Salles, "The double life of the Ku protein: facing the DNA breaks and the extracellular environment," Cell Cycle, vol. 4, no. 3, pp. 438 441, 2005.

[22] M. Koike and A. Koike, "The Ku70-binding site of Ku80 is required for the stabilization of $\mathrm{Ku} 70$ in the cytoplasm, for the nuclear translocation of Ku80, and for Ku80-dependent DNA repair," Experimental Cell Research, vol. 305, no. 2, pp. 266276, 2005.

[23] A. Seluanov, J. Danek, N. Hause, and V. Gorbunova, "Changes in the level and distribution of $\mathrm{Ku}$ proteins during cellular senescence," DNA Repair, vol. 6, no. 12, pp. 1740-1748, 2007.

[24] B. J. Lamarche, N. I. Orazio, and M. D. Weitzman, "The MRN complex in double-strand break repair and telomere maintenance," FEBS Letters, vol. 584, no. 17, pp. 3682-3695, 2010.

[25] R. B. West, M. Yaneva, and M. R. Lieber, "Productive and nonproductive complexes of $\mathrm{Ku}$ and DNA-dependent protein kinase at DNA termini," Molecular and Cellular Biology, vol. 18 , no. 10 , pp. 5908-5920, 1998.

[26] K. Meek, P. Douglas, X. Cui, Q. Ding, and S. P. LeesMiller, "trans autophosphorylation at DNA-dependent protein kinase's two major autophosphorylation site clusters facilitates end processing but not end joining," Molecular and Cellular Biology, vol. 27, no. 10, pp. 3881-3890, 2007.

[27] N. Uematsu, E. Weterings, K. Yano et al., "Autophosphorylation of DNA-PK $\mathrm{CS}_{C S}$ regulates its dynamics at DNA doublestrand breaks," Journal of Cell Biology, vol. 177, no. 2, pp. 219229, 2007.

[28] N. S. A. McElhinny, C. M. Snowden, J. McCarville, and D. A. Ramsden, "Ku recruits the XRCC4-ligase IV complex to DNA ends," Molecular and Cellular Biology, vol. 20, no. 9, pp. 29963003, 2000.

[29] S. Costantini, L. Woodbine, L. Andreoli, P. A. Jeggo, and A. Vindigni, "Interaction of the $\mathrm{Ku}$ heterodimer with the DNA ligase IV/Xrcc4 complex and its regulation by DNA-PK," DNA Repair, vol. 6, no. 6, pp. 712-722, 2007.

[30] P. Y. Wu, P. Frit, L. Malivert et al., "Interplay between Cernunnos-XLF and nonhomologous end-joining proteins at DNA ends in the cell," Journal of Biological Chemistry, vol. 282, no. 44, pp. 31937-31943, 2007.

[31] S. E. Critchlow, R. P. Bowater, and S. P. Jackson, "Mammalian DNA double-strand break repair protein XRCC4 interacts with DNA ligase IV," Current Biology, vol. 7, no. 8, pp. 588598, 1997.

[32] Y. Ma, H. Lu, B. Tippin et al., "A biochemically defined system for mammalian nonhomologous DNA end joining," Molecular Cell, vol. 16, no. 5, pp. 701-713, 2004.

[33] K. N. Mahajan, S. A. Nick McElhinny, B. S. Mitchell, and D. A. Ramsden, "Association of DNA polymerase $\mu(\operatorname{pol} \mu)$ with $\mathrm{Ku}$ and ligase IV: role for pol $\mu$ in end-joining double-strand break repair," Molecular and Cellular Biology, vol. 22, no. 14, pp. 5194-5202, 2002.

[34] C. J. Tsai, S. A. Kim, and G. Chu, "Cernunnos/XLF promotes the ligation of mismatched and noncohesive DNA ends," Proceedings of the National Academy of Sciences of the United States of America, vol. 104, no. 19, pp. 7851-7856, 2007.

[35] H. Wang, A. R. Perrault, Y. Takeda, W. Qin, H. Wang, and G. Iliakis, "Biochemical evidence for Ku-independent backup pathways of NHEJ," Nucleic Acids Research, vol. 31, no. 18, pp. 5377-5388, 2003.

[36] P. Bundock, H. van Attikum, and P. Hooykaas, "Increased telomere length and hypersensitivity to DNA damaging agents in an Arabidopsis KU70 mutant," Nucleic Acids Research, vol. 30, no. 15, pp. 3395-3400, 2002.

[37] J. Friesner and A. B. Britt, "Ku80 and DNA ligase IV plants are sensitive to ionizing radiation and defective in T-DNA integration," Plant Journal, vol. 34, no. 4, pp. 427-440, 2003.

[38] M. E. Gallego, J. Y. Bleuyard, S. Daoudal-Cotterell, N. Jallut, and C. I. White, "Ku80 plays a role in non-homologous recombination but is not required for T-DNA integration in Arabidopsis," Plant Journal, vol. 35, no. 5, pp. 557-565, 2003.

[39] K. Riha, J. M. Watson, J. Parkey, and D. E. Shippen, “Telomere length deregulation and enhanced sensitivity to genotoxic stress in Arabidopsis mutants deficient in Ku70," EMBO Journal, vol. 21, no. 11, pp. 2819-2826, 2002.

[40] H. van Attikum, P. Bundock, R. M. Overmeer, L. Y. Lee, S. B. Gelvin, and P. J. J. Hooykaas, "The Arabidopsis AtLIG4 gene is required for the repair of DNA damage, but not for the integration of Agrobacterium T-DNA," Nucleic Acids Research, vol. 31, no. 14, pp. 4247-4255, 2003.

[41] C. E. West, W. M. Waterworth, G. W. Story, P. A. Sunderland, Q. Jiang, and C. M. Bray, "Disruption of the Arabidopsis AtKu80 gene demonstrates an essential role for AtKu80 protein in efficient repair of DNA double-strand breaks in vivo," Plant Journal, vol. 31, no. 4, pp. 517-528, 2002. 
[42] J. Li, M. Vaidya, C. White, A. Vainstein, V. Citovsky, and T. Tzfira, "Involvement of KU80 in T-DNA integration in plant cells," Proceedings of the National Academy of Sciences of the United States of America, vol. 102, no. 52, pp. 19231-19236, 2005.

[43] P. Bundock and P. Hooykaas, "Severe developmental defects, hypersensitivity to DNA-damaging agents, and lengthened telomeres in Arabidopsis MRE11 mutants," Plant Cell, vol. 14, no. 10, pp. 2451-2462, 2002.

[44] J. M. Alonso, A. N. Stepanova, T. Leisse et al., "Genome-wide insertional mutagenesis of Arabidopsis thaliana," Science, vol. 301, no. 5633, pp. 653-657, 2003.

[45] S. de Pater, L. W. Neuteboom, J. E. Pinas, P. J. J. Hooykaas, and B. J. van der Zaal, "ZFN-induced mutagenesis and genetargeting in Arabidopsis through Agrobacterium-mediated floral dip transformation," Plant Biotechnology Journal, vol. 7, no. 8, pp. 821-835, 2009.

[46] M. Menke, I. Chen, K. J. Angelis, and I. Schubert, "DNA damage and repair in Arabidopsis thaliana as measured by the comet assay after treatment with different classes of genotoxins," Mutation Research, vol. 493, no. 1-2, pp. 87-93, 2001.

[47] J. Schirawski, S. Planchais, and A.-L. Haenni, "An improved protocol for the preparation of protoplasts from an established Arabidopsis thaliana cell suspension culture and infection with RNA of turnip yellow mosaic tymovirus: a simple and reliable method," Journal of Virological Methods, vol. 86, no. 1, pp. 8594, 2000.

[48] A. C. Vergunst, B. Schrammeijer, A. den Dulk-Ras, C. M. T. de Vlaam, T. J. G. Regensburg-Tuink, and P. J. J. Hooykaas, "VirB/D4-dependent protein translocation from Agrobacterium into plant cells," Science, vol. 290, no. 5493, pp. 979$982,2000$.

[49] A. M. Bravo-Angel, B. Hohn, and B. Tinland, "The omega sequence of VirD2 is important but not essential for efficient transfer of T-DNA by Agrobacterium tumefaciens," Molecular Plant-Microbe Interactions, vol. 11, no. 1, pp. 57-63, 1998.

[50] S. J. Clough and A. F. Bent, "Floral dip: a simplified method for Agrobacterium-mediated transformation of Arabidopsis thaliana," Plant Journal, vol. 16, no. 6, pp. 735-743, 1998.

[51] M. Koike, T. Shiomi, and A. Koike, "Dimerization and Nuclear Localization of Ku Proteins," Journal of Biological Chemistry, vol. 276, no. 14, pp. 11167-11173, 2001.

[52] R. M. Burger, J. Peisach, and S. B. Horwitz, "Activated bleomycin. A transient complex of drug, iron, and oxygen that degrades DNA," Journal of Biological Chemistry, vol. 256, no. 22, pp. 11636-11644, 1981.

[53] P. J. O'Connor, "Interaction of chemical carcinogens with macromolecules," Journal of Cancer Research and Clinical Oncology, vol. 99, no. 1-2, pp. 167-186, 1981.

[54] J. D. Moore, O. Yazgan, Y. Ataian, and J. E. Krebs, "Diverse roles for histone $\mathrm{H}_{2} \mathrm{~A}$ modifications in DNA damage response pathways in yeast," Genetics, vol. 176, no. 1, pp. 15-25, 2007.

[55] J. Kozak, C. E. West, C. White, J. A. da Costa-Nunes, and K. J. Angelis, "Rapid repair of DNA double strand breaks in Arabidopsis thaliana is dependent on proteins involved in chromosome structure maintenance," DNA Repair, vol. 8, no. 3, pp. 413-419, 2009.

[56] A. Nussenzweig, K. Sokol, P. Burgman, L. Li, and G. C. Li, "Hypersensitivity of Ku80-deficient cell lines and mice to DNA damage: the effects of ionizing radiation on growth, survival, and development," Proceedings of the National Academy of Sciences of the United States of America, vol. 94, no. 25, pp. 13588-13593, 1997.
[57] Y. Gu, K. J. Seidl, G. A. Rathbun et al., "Growth retardation and leaky SCID phenotype of Ku70-deficient mice," Immunity, vol. 7, no. 5, pp. 653-665, 1997.

[58] R. Hakem, "DNA-damage repair; the good, the bad, and the ugly," EMBO Journal, vol. 27, no. 4, pp. 589-605, 2008.

[59] E. Rampakakis, D. Di Paola, and M. Zannis-Hadjopoulos, "Ku is involved in cell growth, DNA replication and G1-S transition," Journal of Cell Science, vol. 121, no. 5, pp. 590-600, 2008.

[60] M. Rathaus, B. Lerrer, and H. Y. Cohen, "DeubiKuitylation: a novel DUB enzymatic activity for the DNA repair protein, Ku70," Cell Cycle, vol. 8, no. 12, pp. 1843-1852, 2009.

[61] M. Lloret, P. C. Lara, E. Bordón et al., "Major vault protein may affect nonhomologous end-joining repair and apoptosis through Ku70/80 and bax downregulation in cervical carcinoma tumors," International Journal of Radiation Oncology Biology Physics, vol. 73, no. 4, pp. 976-979, 2009.

[62] I. P. Trougakos, M. Lourda, M. H. Antonelou et al., "Intracellular clusterin inhibits mitochondrial apoptosis by suppressing p53-activating stress signals and stabilizing the cytosolic Ku70bax protein complex," Clinical Cancer Research, vol. 15, no. 1, pp. 48-59, 2009.

[63] J. R. Walker, R. A. Corpina, and J. Goldberg, "Structure of the $\mathrm{Ku}$ heterodimer bound to dna and its implications for doublestrand break repair," Nature, vol. 412, no. 6847, pp. 607-614, 2001.

[64] C. Featherstone and S. P. Jackson, "Ku, a DNA repair protein with multiple cellular functions?" Mutation Research, vol. 434, no. 1, pp. 3-15, 1999.

[65] H. Li, Y. J. Choi, M. A. Hanes, T. Marple, H. Vogel, and P. Hasty, "Deleting Ku70 is milder than deleting Ku80 in p53mutant mice and cells," Oncogene, vol. 28, no. 16, pp. 18751878, 2009.

[66] T. Hruz, O. Laule, G. Szabo et al., "Genevestigator V3: a reference expression database for the meta-analysis of transcriptomes," Advances in Bioinformatics, vol. 2008, Article ID 420747, 5 pages, 2008.

[67] E. Mladenov and G. Iliakis, "Induction and repair of DNA double strand breaks: the increasing spectrum of nonhomologous end joining pathways," Mutation Research, vol. 711, no. 1-2, pp. 61-72, 2011.

[68] A. Nussenzweig and M. C. Nussenzweig, "A backup DNA repair pathway moves to the forefront," Cell, vol. 131, no. 2, pp. 223-225, 2007. 

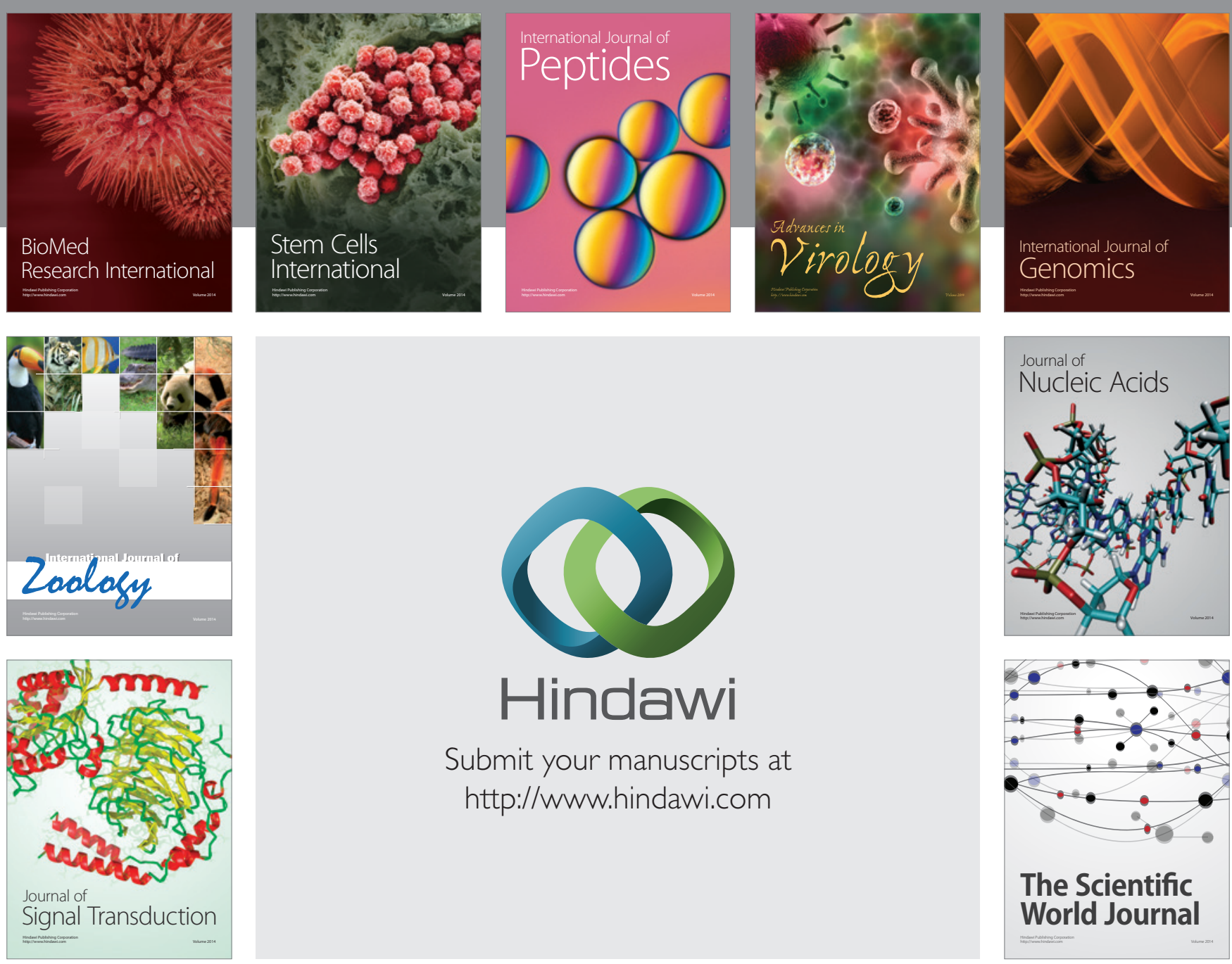

Submit your manuscripts at

http://www.hindawi.com
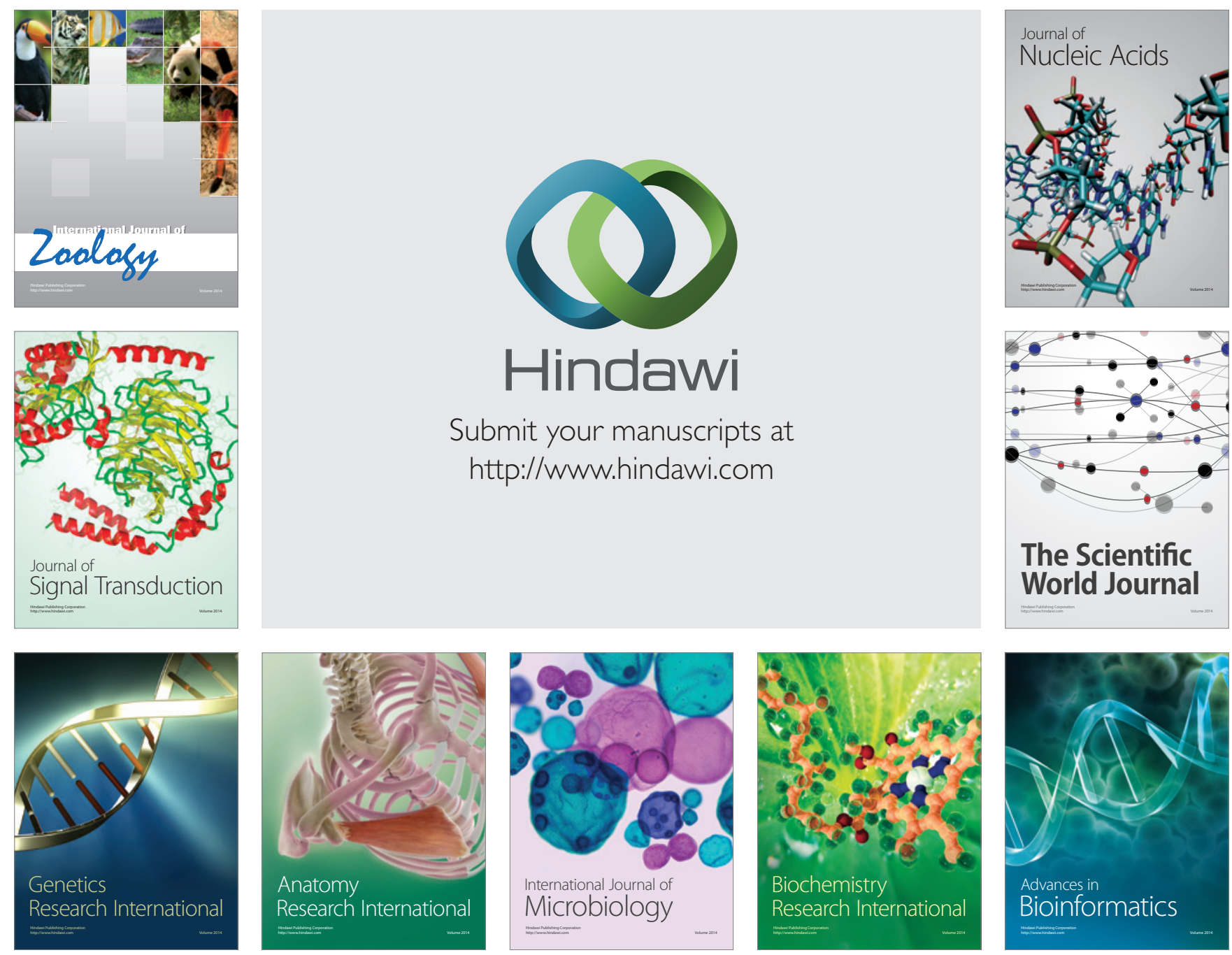

The Scientific World Journal
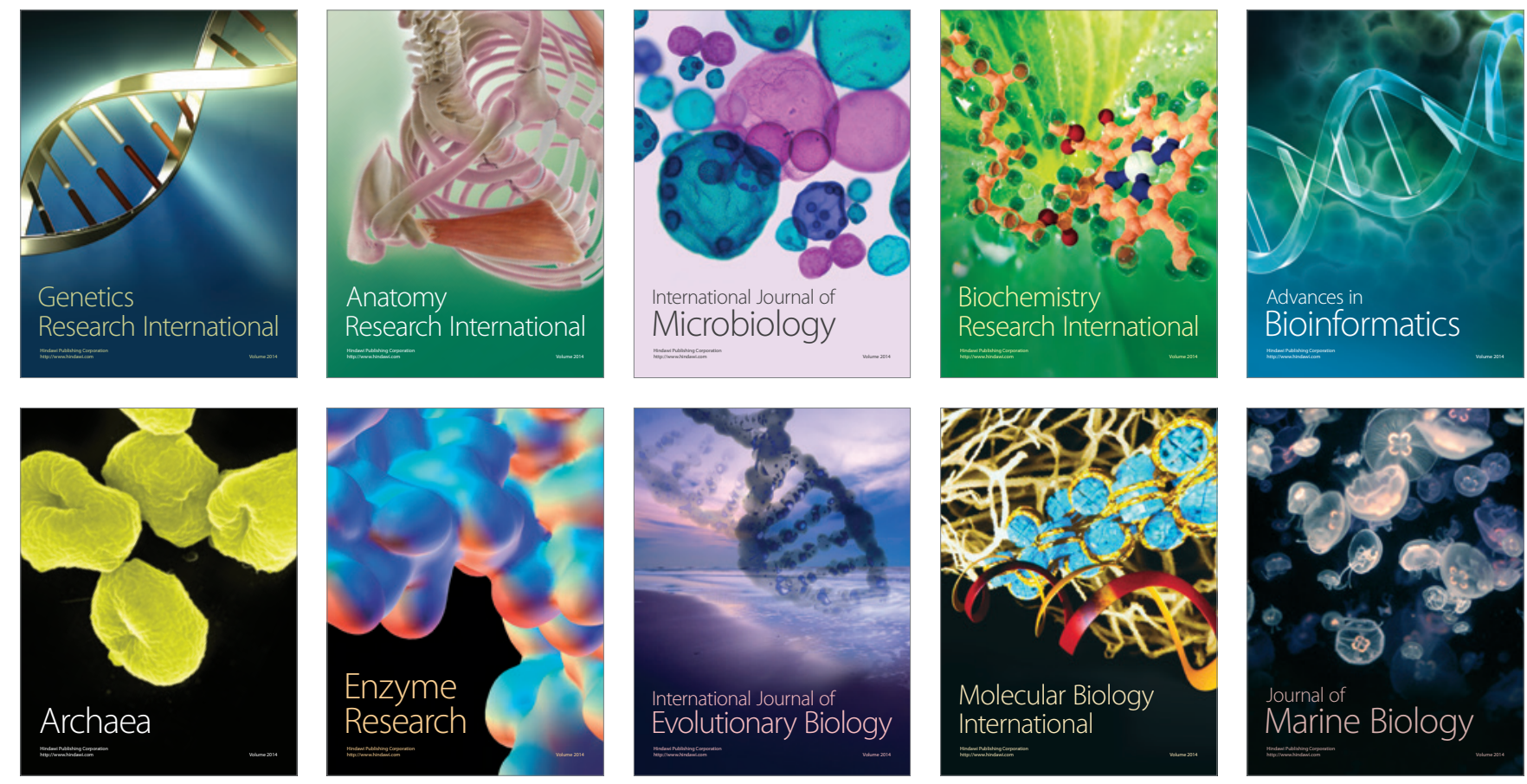